Asian J. Med. Biol. Res. 2021, 7 (1), 40-47; doi: 10.3329/ajmbr.v7i1.53307

\author{
Asian Journal of \\ Medical and Biological Research \\ ISSN 2411-4472 (Print) 2412-5571 (Online) \\ www.ebupress.com/journal/ajmbr
}

\title{
Article \\ Effects of reduced rates of phosphorus and sulphur on the growth and yield of BRRI dhan29
}

\author{
S. M. Ashiful Islam, Md. Abul Hashem, Tahsina Sharmin Hoque* and Md. Rafiqul Islam \\ Department of Soil Science, Bangladesh Agricultural University, Mymensingh-2202, Bangladesh \\ *Corresponding author: Dr. Tahsina Sharmin Hoque, Professor, Department of Soil Science, Bangladesh \\ Agricultural University, Mymensingh-2202, Bangladesh. Phone: +8801720450650; E-mail: \\ tahsinasharmin@bau.edu.bd
}

Received: 04 March 2021/Accepted: 27 March 2021/ Published: 31 March 2021

\begin{abstract}
Balanced fertilization is a pre-requisite for better rice production and it is necessary to determine optimum combination of nutrient elements for application. An experiment was conducted at the Soil Science Field Laboratory of Bangladesh Agricultural University, Mymensingh during Boro season to investigate the effects of reduced rates of phosphorus $(\mathrm{P})$ and sulphur $(\mathrm{S})$ on the growth, yield, nutrient content and uptake by rice. The experiment was laid out in a Randomized Complete Block Design (RCBD) with three replications and eight treatments viz. $\mathrm{T}_{1}$ : Control, $\mathrm{T}_{2}$ : Recommended Fertilizer Dose (RFD), $\mathrm{T}_{3}$ : RFD -20\% P, $\mathrm{T}_{4}:$ RFD-40\% P, $\mathrm{T}_{5}$ : RFD-20\% S, $\mathrm{T}_{6}$ : RFD-40\% S, T 7 : RFD-20\% PS and $\mathrm{T}_{8}$ : RFD-40\% PS. The recommended fertilizer doses were $125 \mathrm{~kg} \mathrm{~N} \mathrm{ha}^{-1}, 25 \mathrm{~kg} \mathrm{P} \mathrm{ha}^{-1}, 70 \mathrm{~kg} \mathrm{~K} \mathrm{ha}^{-1}, 15 \mathrm{~kg} \mathrm{~S} \mathrm{ha}^{-1}$ and $3 \mathrm{~kg} \mathrm{Zn} \mathrm{ha}{ }^{-1}$ supplied from urea, TSP, MoP, gypsum and zinc sulphate, respectively. There was significant effect of reduced rates of $\mathrm{P}$ and $\mathrm{S}$ fertilizers on rice yield compared to control. The highest grain yield of $5.10 \mathrm{t} \mathrm{ha}^{-1}$ and straw yield of $7.02 \mathrm{t} \mathrm{ha}^{-1}$ were recorded from treatment $\mathrm{T}_{2}$ (RFD) that produced the maximum values of all the yield components and the highest content and uptake of nutrients. The performance of $\mathrm{T}_{2}$ and $\mathrm{T}_{3}(\mathrm{RFD}-20 \% \mathrm{P}$ ) was statistically similar in producing yield parameters, yields, nutrient contents and uptake by rice. Again, $20 \%$ reduced rate of $\mathrm{S}\left(\mathrm{T}_{5}\right)$ or of $\mathrm{P}$ and $\mathrm{S}\left(\mathrm{T}_{7}\right)$ caused significant yield reduction, poor yield parameters and less nutrient uptake compared to $\mathrm{T}_{2}$. Thus, the recommended fertilizer dose and the treatments where $20 \% \mathrm{P}$ was reduced from the RFD are equally efficient in increasing yield as well as enhancing nutritional quality of rice. This reduction of chemical fertilizer could help lessen the cost of rice production with decreasing environmental risk.
\end{abstract}

Keywords: Reduced use, fertilizer dose, grain and straw yields, nutrient content and uptake, rice

\section{Introduction}

In Bangladesh, rice is the staple food of about 150 million people of Bangladesh providing nearly $48 \%$ of rural employment, about two-third of total calorie supply and about one-half of the total protein intakes of an average person in the country (BBS, 2018). Importantly, about $80 \%$ of the total cultivable land is used for production of rice that contributes one-half of the agricultural GDP and one-sixth of the national income in Bangladesh (BBS, 2018). Out of total 36.4 million metric tons rice production in this country during the year 2018/19, boro, aman and aus accounted for 53.8, 38.6 and 7.6\%, respectively (Ahmed and Bakhtiar, 2020).

Soil is the store house of plant nutrients. Plants derive 14 essential nutrient elements from the soil (White and Brown, 2010). Among the plant nutrients, phosphorus (P) is a major essential plant nutrient element that plays a vital role in several physiological processes viz. photosynthesis, respiration, energy storage and cell division etc. and is an important structural component of nucleic acids (DNA and RNA), enzymes and co-enzymes (Chang et al., 2007; Amanullah, 2011; Vahed et al., 2012). For rice plants, P stimulates early root growth and development, encourages more active tillering and promotes early flowering, maturity and good grain development. So, to achieve maximum rice yields, it is essential to have sufficient content of $\mathrm{P}$ in soil. 
Phosphorus fertilizer is one of the key inputs for increasing crop yield and nutrient concentration of rice (Dastan et al., 2012). However, $\mathrm{P}$ accumulation in cultivated soils is a concern for non-point environmental pollution and for efficiency of $\mathrm{P}$ resources as a result of excessive $\mathrm{P}$ inputs ( $\mathrm{Li}$ et al., 2010). Phosphorus accumulation in the soil due to excessive $\mathrm{P}$ applications can cause a risk of $\mathrm{P}$ loss and contribute to eutrophication of surface waters (Xi et al., 2016). The application of $\mathrm{P}$ fertilizer either in excess or less than optimum rate affects both yield and quality of crops to a remarkable extent. Again, sulphur (S) is another essential macronutrient for plants which plays a vital role in metabolic reactions including protein and oil synthesis, formation of chlorophyll and activation of enzymes (Singh et al., 2012). Increasing S levels in rice improves leaf area index, tiller number, dry matter production, harvest index and sulphur content and uptake in rice (Chandel et al., 2003; Ram et al., 2014). In recent years, $S$ deficiency has been receiving much attention as a major limiting factor for wetland rice and so, in fertilizer schedule, it is commonly included (Islam et al., 2009). Sulphur deficiency affects not only the growth and yield of rice by reducing leaf and tiller number, plant height, panicle length and dry weight but also the protein quality through its effect on the synthesis of certain amino acids such as cysteine and methionine. The use of almost $S$ free fertilizer such as urea and triple super phosphate (TSP) may be an important reason for widespread occurrence of $S$ deficiency problem. So, to get high grain yield and to attain maximum profitability, the appropriate fertilizer input in rice is necessary (Khuang et al., 2008).

Large scale use of chemical fertilizers has created a potential health hazard, reduced microbial population and earthworm activities, affecting soil health and reduced utility of water bodies for men, animals and fishes (Bhuiyan and Karim, 1999; Savci, 2012; Chandini et al., 2019). Global environmental pollution can be lessened to some extent by application of reduced rates of chemical fertilizers. Moreover, chemical fertilizers are likely to be even more costly in near future. The actual recommended rates of $\mathrm{P}$ and $\mathrm{S}$ fertilizer not only maintain soil fertility for sustainable agriculture but also save part of the cost of crop production. Considering these points, the present study was undertaken to investigate the effects of reduced rates of $\mathrm{P}$ and $\mathrm{S}$ fertilizers on the growth, yield, nutrient content and uptake by rice for sustainable and profitable food production in Bangladesh.

\section{Materials and Methods}

\subsection{Experimental site and soil}

The experiment was carried out at the Soil Science Field Laboratory of Bangladesh Agricultural University, Mymensingh during rabi season. The experimental site belongs to Sonatala series under the AEZ-9 (Old Brahmaputra Floodplain) and the soil was silt loam in texture having $\mathrm{pH}$ 6.2, organic matter content 1.18\%, total N 0.09\%, available P $17.6 \mathrm{ppm}$, available K $24.9 \mathrm{meq} / 100 \mathrm{~g}$ soil and available S $13.76 \mathrm{ppm}$.

\subsection{Treatments and experimental design}

The experiment was laid out in a Randomized Complete Block Design (RCBD) with eight treatments having three replications. The treatments were $\mathrm{T}_{1}$ (control), $\mathrm{T}_{2}(\mathrm{RFD}), \mathrm{T}_{3}(\mathrm{RFD}-20 \% \mathrm{P}), \mathrm{T}_{4}(\mathrm{RFD}-40 \% \mathrm{P}), \mathrm{T}_{5}(\mathrm{RFD}$ $-20 \% \mathrm{~S}), \mathrm{T}_{6}(\mathrm{RFD}-40 \% \mathrm{~S}), \mathrm{T}_{7}(\mathrm{RFD}-20 \% \mathrm{PS})$, and $\mathrm{T}_{8}$ (RFD - 40\% PS). Each replication was represented by a block and each block was divided into eight unit plots for the selected treatment. The treatments were randomly distributed to unit plots in each block. There were 24 unit plots and the size of unit plot was $4 \mathrm{~m} \times 2.5$ $\mathrm{m}$. The spacing between blocks was $1 \mathrm{~m}$ and between plots was $0.5 \mathrm{~m}$.

\subsection{Land preparation and seedling transplanting}

The land was made saturated with irrigation water and prepared by successive ploughing, cross ploughing and laddering. All kinds of weeds, stubbles and crop residues were removed from the field before final ploughing and leveling. BRRI dhan29, a high yielding variety of rice was used as a test crop in this experiment. Forty day old seedlings were transplanted in the experimental plots by maintaining a distance of $20 \mathrm{~cm}$ from row to row and $20 \mathrm{~cm}$ from plant to plant. Three seedlings were used in each hill.

\subsection{Fertilizer application}

The doses of N, P, K, S and Zn were $180,24,76,12$ and $1.5 \mathrm{~kg} \mathrm{ha}^{-1}$, respectively following the Fertilizer Recommendation Guide (FRG, 2018) in the form of urea, triple super phosphate (TSP), muriate of potash (MoP), gypsum and zinc oxide, respectively. All the fertilizers except urea were applied as basal during final land preparation as per treatments. Urea was applied in three equal splits as top dressing. The first installment was applied at 15 days after transplanting (DAT) i.e. at seedling establishment stage, second installment at 30 DAT i.e. at maximum tillering stage and third installment at 50 DAT i.e. panicle initiation stage of rice. 


\subsection{Intercultural operations}

Some intercultural practices such as irrigation, weeding, drainage, pest control etc. were performed as and when necessary to ensure and maintain the normal growth of the crop.

\subsection{Harvesting}

The test crop was harvested at full maturity. The grain yield was obtained on $14 \%$ moisture basis while the straw yield was recorded on sundry basis. Five hills were randomly selected from each plot of the block and data on growth and yield parameters including plant height, number of effective tillers per hill ${ }^{-1}$, panicle length, number of filled grains panicle ${ }^{-1}$ and 1000-grain weight were recorded.

\subsection{Preparation and analysis of plant samples}

The representative grain and straw samples were dried in an oven at $65^{\circ} \mathrm{C}$ for about 48 hours and then ground by a grinding machine. The ground samples were passed through a 20-mesh sieve, stored in paper bags and finally kept in desiccators for chemical analysis. The contents of N, P, K and S in plant samples were determined following semi-micro Kjeldahl method (Bremner and Mulvaney, 1982), modified Olsen method (Olsen et al., 1954), $\mathrm{NH}_{4} \mathrm{OAc}$ extraction method (Knudsen et al., 1982), and $\mathrm{CaCl}_{2}$ extraction method (Williams and Steinbergs, 1959), respectively. The nutrient uptakes were calculated from the yield $\left(\mathrm{kg} \mathrm{ha}^{-1}\right)$ and nutrient content (\%) data.

\subsection{Collection, preparation and analysis of initial soil samples}

The initial soil samples were collected at a depth of 0-15 cm from the surface by means of auger from each plot of the blocks. After removing weeds, plant roots, stubbles, stones, etc., the collected soil samples were air-dried at room temperature, mixed thoroughly, crushed, sieved through a 20-mesh sieve and preserved in clean plastic bags for subsequent chemical and mechanical analyses. Particle size analysis of soil was performed by hydrometer method (Black, 1965) and the textural classes were determined by plotting of the values for \% sand, $\%$ silt and \% clay to the Marshall's Triangular Coordinate following the USDA system. Soil $\mathrm{pH}$ (1:2.5 soilwater) was measured by glass electrode $\mathrm{pH}$ meter method (Jackson, 1973) and organic matterwas determined by Walkley and Black method (Walkley and Black, 1934). Total N was measured by Semi-micro Kjeldahl method (Bremner and Mulvaney, 1982), available $\mathrm{P}$ by Olsen method (Olsen et al., 1954), available K by flamephotometer after extraction with $1 \mathrm{~N} \mathrm{NH}_{4} \mathrm{OAc}$ at $\mathrm{pH} 7.0$ (Knudsen et al., 1982), available $\mathrm{S}$ by extracting soil samples with $\mathrm{CaCl}_{2}$ solution $(0.15 \%)$ and by measuring turbidity by spectrophotometer (Williams and Steinbergs, 1959) method.

\subsection{Statistical analysis}

The collected data on various parameters were statistically analyzed using the MSTAT-computer package program (Russell, 1986) in order to get the level of significance and the differences among treatment means were adjudged by Duncan's New Multiple Range Test (DMRT) at 5\% level of probability (Gomez and Gomez, 1984).

\section{Results and Discussion}

\subsection{Effect of different treatments on the yield components of rice (BRRI dhan29)}

Yield contributing characters such as plant height, panicle length, number of effective tiller hill $^{-1}$ and number of filled grains panicle ${ }^{-1}$ of BRRI dhan 29 were significantly affected by different treatments under study while weight of 1000-grain remained statistically unaffected (Table 1). The tallest plant of $82.84 \mathrm{~cm}$, maximum number of effective tillers hill ${ }^{-1}$ of 13.20 , highest panicle length of $24.84 \mathrm{~cm}$, maximum number of filled grains panicle $^{-1}$ of 153 and highest weight of 1000-grain of $22.21 \mathrm{~g}$ were found in $\mathrm{T}_{2}$ (100\% RFD) which were statistically identical to those observed in $\mathrm{T}_{3}(\mathrm{RFD}-20 \% \mathrm{P})$. The treatment $\mathrm{T}_{3}$ produced the second highest values for plant height $(82.23 \mathrm{~cm})$, number of effective tillers hill ${ }^{-1}(13.09)$, panicle length $(24.26 \mathrm{~cm})$, number of filled grains panicle ${ }^{-1}$ (92.33) and 1000-grain weight (22.21 g). On the other hand, the shortest plant of 64.17 $\mathrm{cm}$, minimum number of effective tillers hill ${ }^{-1}$ of 9.17 , lowest panicle length of $20.32 \mathrm{~cm}$, minimum number of filled grains panicle ${ }^{-1}$ of 78 and lowest weight of 1000-grain of $20.05 \mathrm{~g}$ were found in $\mathrm{T}_{1}$ (control). The positive responses of $\mathrm{P}$ and $\mathrm{S}$ application on the growth and yield parameters of rice were also reported by Massawe and Mrema (2017), Islam et al. (2016) and Sharma et al. (2009). The results showed that use of recommended doses of chemical fertilizers was more efficient in improving yield parameters of rice. However, $20 \%$ reduced rate of $\mathrm{P}$ performed more or less similar with recommended doses. Our results are partially or fully accorded to the findings of Hasan et al. (2008) and Baki et al. (2015) who reported statistically similar yield parameters from 
recommended fertilizers and from $20 \%$ reduction of $\mathrm{N}, \mathrm{P}$ or K from recommended doses. The significance of $\mathrm{P}$ and $\mathrm{S}$ on improving growth and yield parameters of rice was demonstrated by several researchers (Ali et al., 2004; Yosef et al., 2013; Uddin et al., 2014).

\subsection{Effect of different treatments on the yield of rice}

Reduced rates of $\mathrm{P}$ and $\mathrm{S}$ fertilizers exerted significant effects on grain yield and straw yield of BRRI dhan 29 (Table 2). The highest grain yield of $5.10 \mathrm{tha}^{-1}$ and straw yield of $7.02 \mathrm{t} \mathrm{ha}^{-1}$ were recorded in $\mathrm{T}_{2}(100 \%$ RFD) and the lowest grain yield of $3.40 \mathrm{tha}^{-1}$ and straw yield of $4.30 \mathrm{t} \mathrm{ha}^{-1}$ were found in $\mathrm{T}_{1}$ (control). The treatment $\mathrm{T}_{3}$ (RFD $-20 \% \mathrm{P}$ ) showed statistically similar behavior with $\mathrm{T}_{2}$ and it produced the second highest grain yield of $5.02 \mathrm{t} \mathrm{ha}^{-1}$ and straw yield of $6.97 \mathrm{t} \mathrm{ha}^{-1}$. The percent increase in rice yield over control ranged from 25.29 to 50 for grain and 44.88to 63.26 for straw where $\mathrm{T}_{2}$ gave the highest yield increase over control. In case of both grain yield and straw yield, the treatments may be ranked in the order $T_{2}>T_{3}>T_{5}>T_{7}>T_{6}>T_{4}>T_{8}>T_{1}$. The results of the present study are also in agreement with the findings of many researchers. The present findings are in partial agreement with those of Hasan et al. (2008) and Baki et al. (2015) where recommended fertilizers were applied but these yields did not vary significantly with the yields observed in the treatments with the reduction of $\mathrm{P}$ or K or S at the rate of $20 \%$ from the recommended doses. Sharma et al. (2009) reported that the grain yield of rice increased significantly when the rate of $\mathrm{P}$ application was increased from 0 to $35 \mathrm{~kg} \mathrm{Pha}^{-1}$ either as DAP or MRP. Islam et al. (2016) and Kalala et al. (2016) revealed that the application of higher dose of $\mathrm{S}$ exerted pronounced effect in producing higher grain and straw yields of rice.

\subsection{Effect of different treatments on $P$ content and uptake in grain and straw of rice}

Phosphorus content in grain and straw of BRRI dhan 29 was significantly influenced by the different treatments (Table 3). In case of grain, the highest $\mathrm{P}$ content $(0.29 \%)$ was found in treatments $\mathrm{T}_{2}(100 \% \mathrm{RFD}), \mathrm{T}_{3}$ (RFD $20 \% \mathrm{P}$ ) and $\mathrm{T}_{5}$ (RFD -20\% S) which were statistically identical to treatment $\mathrm{T}_{7}$ (RFD -20\% PS) that recorded $0.28 \%$ P. In case of straw, the maximum $\mathrm{P}$ content $(0.17 \%)$ was observed in $\mathrm{T}_{2}$ which was not statistically different from those found in $\mathrm{T}_{3}, \mathrm{~T}_{5}$ and $\mathrm{T}_{7}$ treatments. The lowest contents of $\mathrm{P}$ in grain $(0.22 \%)$ and straw $(0.75 \%)$ were noted in $\mathrm{T}_{1}$ where no fertilizer was applied. Phosphorus uptake in rice was also significantly affected by various treatments under study (Table 3$)$. The maximum uptake of $P$ in grain $\left(13.60 \mathrm{~kg} \mathrm{ha}^{-1}\right)$, straw $\left(10.83 \mathrm{~kg} \mathrm{ha}^{-1}\right)$ and total $\left(24.43 \mathrm{~kg} \mathrm{ha}^{-1}\right)$ were also recorded in $\mathrm{T}_{2}$ which was identical to those observed in $\mathrm{T}_{3}$. Treatment $\mathrm{T}_{3}$ produced the second highest uptake of $\mathrm{P}$ in grain $\left(12.99 \mathrm{~kg} \mathrm{ha}^{-1}\right)$, straw $\left(10.28 \mathrm{~kg} \mathrm{ha}^{-1}\right)$ and total $\left(23.27 \mathrm{~kg} \mathrm{ha}^{-1}\right)$. On the other hand, the control treatment recorded the lowest uptake of $\mathrm{P}$ in grain $\left(6.91 \mathrm{~kg} \mathrm{ha}^{-1}\right)$, straw $\left(5.03 \mathrm{~kg} \mathrm{ha}^{-1}\right)$ and total $\left(11.94 \mathrm{~kg} \mathrm{ha}^{-1}\right)$. The reduction of recommended doses of fertilizers by $20 \%$ did not significantly reduce $\mathrm{P}$ content and uptake in rice which was demonstrated by Baki et al. (2015) and Hasan et al. (2008). Phosphorus rates and application timings significantly affect phosphorus uptake in rice (Sanusan et al., 2009). The favorable effect of higher availability of $P$ in soil and different levels of $P$ applied ondry matter production and content ultimately reflectinsignificant increase in $\mathrm{P}$ uptake by rice (Archana et al., 2017).

\subsection{Effect of different treatments on $S$ content and uptake in grain and straw of rice}

Reduced use of $\mathrm{P}$ and $\mathrm{S}$ fertilizers had no significant effect on $\mathrm{S}$ content in rice but exerted significant influence on $S$ uptake by rice grain, straw and in total (grain + straw) (Table 4). The maximum S content in grain $(0.14 \%)$ was recorded in $T_{2}, T_{3}$ and $T_{5}$ treatments whereas the highest $S$ content in straw $(0.12 \%)$ was noted in $T_{2}$ and $T_{5}$ treatments. The minimum $\mathrm{S}$ contents in grain $(0.12 \%)$ and straw $(0.10 \%)$ were recorded in control $\left(\mathrm{T}_{1}\right)$. On the other hand, S uptake in grain, straw and total varied from 3.64 to $661.25,112.88$ to 555.59 and 336.15 to $1116.84 \mathrm{~kg} \mathrm{ha}^{-1}$, respectively. On the other hand, the values for grain S uptake, straw S uptake and total S uptake ranged from 3.10 to $6.48,3.86$ to 7.36 and 7.50 to $13.93 \mathrm{~kg} \mathrm{ha}^{-1}$, respectively. For $\mathrm{S}$ uptake (grain, straw and total), the highest values were obtained from $\mathrm{T}_{2}(100 \% \mathrm{RFD})$ which were identical to those found in $\mathrm{T}_{3}$ (RFD $20 \%$ P).The lowest values of $\mathrm{S}$ uptakes (grain, straw and total) were observed in control $\left(\mathrm{T}_{1}\right)$. Similar with our findings, Baki et al. (2015) and Hasan et al. (2008) showed no significant reduction in S content and uptake in rice with $20 \%$ reduction of recommended fertilizer doses. Chandel et al. (2003) and Islam et al. (2016) showed that $\mathrm{S}$ content in rice grain and straw was significantly increased by the application of higher rates of $\mathrm{S}$. 
Table 1. Effect of reduced rates of $P$ and $S$ on the yield components of rice.

\begin{tabular}{|l|l|l|l|l|l|}
\hline Treatments & $\begin{array}{l}\text { Plant } \\
\text { height }(\mathbf{c m})\end{array}$ & $\begin{array}{l}\text { Number of effective } \\
\text { tillers hill }^{-1}\end{array}$ & $\begin{array}{l}\text { Panicle length } \\
(\mathbf{c m})\end{array}$ & $\begin{array}{l}\text { Number of filled }_{\text {grains panicle }^{-1}} \\
\text { (1000-grain weight } \\
(\mathbf{g})\end{array}$ \\
\hline $\mathrm{T}_{1}$ & $64.17 \mathrm{f}$ & $9.17 \mathrm{c}$ & $20.32 \mathrm{e}$ & $78.00 \mathrm{f}$ & 20.05 \\
\hline $\mathrm{T}_{2}$ & $82.84 \mathrm{a}$ & $13.20 \mathrm{a}$ & $24.84 \mathrm{a}$ & $92.33 \mathrm{a}$ & 22.21 \\
\hline $\mathrm{T}_{3}$ & $82.23 \mathrm{ab}$ & $13.09 \mathrm{a}$ & $24.26 \mathrm{ab}$ & $91.67 \mathrm{ab}$ & 22.09 \\
\hline $\mathrm{T}_{4}$ & $77.68 \mathrm{c}$ & $11.30 \mathrm{~b}$ & $23.82 \mathrm{~b}$ & $90.00 \mathrm{~b}$ & 20.79 \\
\hline $\mathrm{T}_{5}$ & $80.15 \mathrm{~b}$ & $11.08 \mathrm{~b}$ & $24.19 \mathrm{ab}$ & $90.33 \mathrm{~b}$ & 21.30 \\
\hline $\mathrm{T}_{6}$ & $79.61 \mathrm{~b}$ & $10.62 \mathrm{bc}$ & $23.80 \mathrm{~b}$ & $88.33 \mathrm{c}$ & 20.77 \\
\hline $\mathrm{T}_{7}$ & $74.53 \mathrm{~d}$ & $11.19 \mathrm{~b}$ & $22.98 \mathrm{c}$ & $86.00 \mathrm{~d}$ & 20.65 \\
\hline $\mathrm{T}_{8}$ & $73.12 \mathrm{de}$ & $10.30 \mathrm{bc}$ & $21.66 \mathrm{~d}$ & $82.00 \mathrm{e}$ & 20.53 \\
\hline $\mathrm{CV} \%$ & 2.03 & 1.04 & 2.41 & 3.77 & 1.02 \\
\hline SE $( \pm)$ & 1.68 & 0.31 & 0.45 & 1.73 & 0.22 \\
\hline $\begin{array}{l}\text { Level of } \\
\text { significance }\end{array}$ & $* *$ & $* *$ & $* *$ & $* *$ & $\mathrm{NS}$ \\
\hline
\end{tabular}

Figures in a column having common letters do not differ significantly at $1 \%$ level of significance. $\mathrm{CV}(\%)=$ Coefficient of variation; SE $( \pm)=$ Standard error of means; $* * *$ Significant at $1 \%$ level of probability.

Table 2. Effect of reduced rates of $P$ and $S$ on the grain and straw yield of rice.

\begin{tabular}{|l|l|l|l|l|}
\hline Treatments & $\begin{array}{l}\text { Grain yield } \\
\left.\mathbf{t ~ h a}^{-\mathbf{1}}\right)\end{array}$ & $\begin{array}{l}\text { Increase over } \\
\text { control }(\mathbf{\%})\end{array}$ & $\begin{array}{l}\text { Straw yield } \\
\left.\mathbf{t ~ h a}^{-\mathbf{1}}\right)\end{array}$ & $\begin{array}{l}\text { Increase over control } \\
(\mathbf{\%})\end{array}$ \\
\hline $\mathrm{T}_{1}$ & $3.40 \mathrm{~g}$ & - & $4.30 \mathrm{f}$ & - \\
\hline $\mathrm{T}_{2}$ & $5.10 \mathrm{a}$ & 50 & $7.02 \mathrm{a}$ & 63.26 \\
\hline $\mathrm{T}_{3}$ & $5.02 \mathrm{ab}$ & 47.65 & $6.97 \mathrm{ab}$ & 62.09 \\
\hline $\mathrm{T}_{4}$ & $4.48 \mathrm{e}$ & 31.76 & $6.29 \mathrm{e}$ & 46.28 \\
\hline $\mathrm{T}_{5}$ & $4.93 \mathrm{~b}$ & 45 & $6.86 \mathrm{~b}$ & 59.53 \\
\hline $\mathrm{T}_{6}$ & $4.65 \mathrm{~cd}$ & 36.76 & $6.33 \mathrm{de}$ & 47.21 \\
\hline $\mathrm{T}_{7}$ & $4.78 \mathrm{c}$ & 40.59 & $6.47 \mathrm{~cd}$ & 50.57 \\
\hline $\mathrm{T}_{8}$ & $4.26 \mathrm{f}$ & 25.29 & $6.23 \mathrm{e}$ & 44.88 \\
\hline $\mathrm{CV} \%$ & 2.97 & - & 2.81 & - \\
\hline SE $( \pm)$ & 0.74 & - & 0.93 & - \\
\hline Level of significance & $* *$ & - & $* *$ & - \\
\hline
\end{tabular}

Figures in a column having common letters do not differ significantly at $1 \%$ level of significance. $\mathrm{CV}(\%)=$ Coefficient of variation; SE $( \pm)=$ Standard error of means; $* *=$ Significant at $1 \%$ level of probability.

Table 3. Effect of reduced rates of $P$ and $S$ on $P$ content and uptake by rice.

\begin{tabular}{|l|l|l|l|l|l|}
\hline \multirow{2}{*}{ Treatments } & \multicolumn{3}{|c|}{ P content (\%) } & \multicolumn{3}{c|}{ P uptake (kg ha $\left.{ }^{-\mathbf{1}}\right)$} \\
\cline { 2 - 6 } & Grain & Straw & Grain & Straw & Total \\
\hline $\mathrm{T}_{1}$ & $0.22 \mathrm{~d}$ & $0.13 \mathrm{c}$ & $6.91 \mathrm{~d}$ & $5.03 \mathrm{~d}$ & $11.94 \mathrm{f}$ \\
\hline $\mathrm{T}_{2}$ & $0.29 \mathrm{a}$ & $0.17 \mathrm{a}$ & $13.60 \mathrm{a}$ & $10.83 \mathrm{a}$ & $24.43 \mathrm{a}$ \\
\hline $\mathrm{T}_{3}$ & $0.29 \mathrm{a}$ & $0.16 \mathrm{ab}$ & $12.99 \mathrm{a}$ & $10.28 \mathrm{a}$ & $23.27 \mathrm{ab}$ \\
\hline $\mathrm{T}_{4}$ & $0.25 \mathrm{c}$ & $0.15 \mathrm{~b}$ & $10.08 \mathrm{c}$ & $8.36 \mathrm{c}$ & $18.44 \mathrm{de}$ \\
\hline $\mathrm{T}_{5}$ & $0.29 \mathrm{a}$ & $0.16 \mathrm{ab}$ & $12.79 \mathrm{ab}$ & $9.83 \mathrm{ab}$ & $22.62 \mathrm{~b}$ \\
\hline $\mathrm{T}_{6}$ & $0.27 \mathrm{~b}$ & $0.15 \mathrm{~b}$ & $11.52 \mathrm{~b}$ & $8.90 \mathrm{bc}$ & $20.42 \mathrm{~cd}$ \\
\hline $\mathrm{T}_{7}$ & $0.28 \mathrm{ab}$ & $0.16 \mathrm{ab}$ & $11.92 \mathrm{~b}$ & $9.45 \mathrm{~b}$ & $21.37 \mathrm{c}$ \\
\hline $\mathrm{T}_{8}$ & $0.25 \mathrm{c}$ & $0.14 \mathrm{bc}$ & $9.70 \mathrm{c}$ & $8.10 \mathrm{c}$ & $17.80 \mathrm{e}$ \\
\hline $\mathrm{CV} \%$ & 3.21 & 1.07 & 4.91 & 2.11 & 3.73 \\
\hline $\mathrm{SE}( \pm)$ & 0.16 & 0.11 & 1.49 & 1.34 & 1.99 \\
\hline $\begin{array}{l}\text { Level } \\
\text { significance }\end{array}$ & $* *$ & $* *$ & $* *$ & $* *$ & $* *$ \\
\hline
\end{tabular}

Figures in a column having common letters do not differ significantly at $1 \%$ level of significance. CV $(\%)=$ Coefficient of variation; SE $( \pm)=$ Standard error of means; $* *=$ Significant at $1 \%$ level of probability. 
Table 4. Effect of reduced rates of $P$ and $S$ on $S$ content and uptake by rice.

\begin{tabular}{|l|l|l|l|l|l|}
\hline \multirow{2}{*}{ Treatments } & \multicolumn{2}{|c|}{ S content (\%) } & \multicolumn{3}{c|}{ S uptake (kg ha $\left.\mathbf{~}^{-1}\right)$} \\
\cline { 2 - 6 } & Grain & Straw & Grain & Straw & Total \\
\hline $\mathrm{T}_{1}$ & 0.12 & 0.10 & $3.64 \mathrm{~d}$ & $3.86 \mathrm{~d}$ & $7.50 \mathrm{e}$ \\
\hline $\mathrm{T}_{2}$ & 0.14 & 0.12 & $6.48 \mathrm{a}$ & $7.45 \mathrm{a}$ & $13.93 \mathrm{a}$ \\
\hline $\mathrm{T}_{3}$ & 0.14 & 0.11 & $6.25 \mathrm{a}$ & $7.12 \mathrm{ab}$ & $13.37 \mathrm{ab}$ \\
\hline $\mathrm{T}_{4}$ & 0.13 & 0.11 & $5.41 \mathrm{c}$ & $6.22 \mathrm{bc}$ & $11.62 \mathrm{c}$ \\
\hline $\mathrm{T}_{5}$ & 0.14 & 0.12 & $6.13 \mathrm{ab}$ & $6.97 \mathrm{~b}$ & $13.10 \mathrm{~b}$ \\
\hline $\mathrm{T}_{6}$ & 0.13 & 0.11 & $5.69 \mathrm{bc}$ & $5.94 \mathrm{c}$ & $11.64 \mathrm{c}$ \\
\hline $\mathrm{T}_{7}$ & 0.13 & 0.11 & $5.90 \mathrm{~b}$ & $5.81 \mathrm{c}$ & $11.71 \mathrm{c}$ \\
\hline $\mathrm{T}_{8}$ & 0.13 & 0.10 & $4.95 \mathrm{c}$ & $5.88 \mathrm{c}$ & $10.82 \mathrm{~d}$ \\
\hline $\mathrm{CV} \%$ & 1.21 & 1.49 & 3.77 & 2.89 & 2.04 \\
\hline SE $( \pm)$ & 0.08 & 0.07 & 0.96 & 1.06 & 1.41 \\
\hline $\begin{array}{l}\text { Level of } \\
\text { significance }\end{array}$ & $\mathrm{NS}$ & $\mathrm{NS}$ & $* *$ & $* *$ & $* *$ \\
\hline
\end{tabular}

Figures in a column having common letters do not differ significantly at $1 \%$ level of significance. CV $(\%)=$ Coefficient of variation; SE $( \pm)=$ Standard error of means; NS = Not significant; $* *=$ Significant at $1 \%$ level of probability.

\section{Conclusions}

From the present study, it is distinct that the recommended dose of fertilizers provided the highest yield of BRRI dhan 29 with better nutrient content and uptake. As the recommended fertilizer doses were calculated based on the soil inherent nutrients and crop demand, it is obvious that application of recommended doses of fertilizers will produce a good yield. However, the results revealed that the recommended fertilizer dose and $20 \%$ reduction of $\mathrm{P}$ from the recommended doses are equally efficient in producing grain and straw yield as well as improving nutritional quality of rice. On the other hand, 20\% reduction of S or both of $\mathrm{P}$ and S from the recommended rates were not similarly effective with recommended fertilizer dose as they produced comparatively lower yield, poor yield characters and nutrient uptake in rice. Imbalanced use of chemical fertilizers is costly in terms of nutrient loss from soil mining, decline in food supply and loss of soil fertility. Application of fertilizers at reduced rates would be helpful to promote the eco-friendly environment and reduce the input cost of rice production. However, a thorough investigation with other rice varieties is needed to draw a reasonable conclusion.

\section{Conflict of interest}

None to declare.

\section{References}

Ahmed A and MM Bakhtiar, 2020. Boro rice procurement in Bangladesh: Implications for policy. International Food Policy Research Institute (IFPRI), Bangladesh Policy Research and Strategy Program, Gulshan, Dhaka.

Ali MM, MS Mian, A Islam, JA Begum and AKM Ferdous, 2004. Interaction effects of sulphur and phosphorus on wetland rice. Asian J. Plant Sci., 3: 597-601.

Archana K, TP Reddy, T Anjaiah and B Padmaja, 2017. Effect of dose and time of application of phosphorus on changes in phosphorus uptake pattern and yield of rice grown on P accumulated soil. Agric. Update, 12: 960965.

Baki MZI, MA Hashem and MR Islam, 2015. Effects of reduced rates of fertilizers on N, P, K, S, and Zn contents and uptakes in BRRI dhan29. Int. J. Nat. Soc. Sci., 2: 66-71.

BBS (Bangladesh Bureau of Statistics), 2018. 45 years Agriculture Statistics of Major Crops (Aus, Amon, Boro, Jute, Potato\& Wheat).Bangladesh Bureau of Statistics, Statistics and Informatics Division (SID), Ministry of Planning, Govt. of the Peoples' Republic of Bangladesh, Dhaka. p. 19.

Bhuiyan SI and ANMR Karim, 1999. Increasing rice production in Bangladesh: Challenges and strategies. Dhaka (Bangladesh): Bangladesh Rice Research Institute and Manila (Philippines): International Rice Research Institute. p. 167.

Bremner JM and CS Mulvaney, 1982. Nitrogen- total. In: Page AL, RH Miller, DR Keeney, (Eds.), Methods of Soil Analysis- Part 2. American Society of Agronomy, Inc. Publisher, Madison, pp. 595-624.

Chandel RS, K Singh, AK Singh and PC Sudhakar, 2003. Effect of sulphur nutrition in rice (Oryza sativa) and mustard (Brassica juncea) grown in sequence. Indian J. Plant Physiol., 8: 155-59. 
Chandini, R Kumar, R Kumar and O Prakash, 2019. The impact of chemical fertilizers on our environment and ecosystem. Res. Trends Environ. Sci., 5: 69-85.

Chang EH, SF Zhang, ZQ Wang, XM Wang and JC Yang, 2007. Effect of nitrogen and phosphorus on the amino acids in root exudates and grains of rice during grain filling. Acta Agron. Sin., 33: 1949-1959.

Dastan S,M Siavoshi, D Zakavi, MA Ghanbaria, R Yadi, DE Ghorbannia, and AR Nasiri, 2012. Application of nitrogen and silicon rates on morphological and chemical lodging related characteristics in rice (Oryza sativa L.) north of Iran. J. Agril. Sci., 4: 12-18.

FRG (Fertilizer Recommendation Guide), 2018. Fertilizer Recommendation Guide -2018. Bangladesh Agricultural Research Council, Farmgate, Dhaka.

Gomez KA andAA Gomez, 1984. Statistical Procedures for Agricultural Research. John Wiley and Sons., New York.

Hasan ABMM, MM Rahman and MA Hashem, 2008. Effect of reduced rates of N, P and K on the yield of rice (Oryza sativa L.) and its nutrient uptake. Agriculturists, 6: 67-76.

Islam AKMS, MS Rana, MM Rahman, MJA Mian, MM Rahman, MA Rahman and N Naher, 2016. Growth, yield and nutrient uptake capacity of rice under different sulphur levels. Turk. J. Agric. Food Sci. Technol., 4: 557-565.

Islam MR, MS Shah and M Jahiruddin, 2009. Effects of different rates and sources of sulphur on the growth and yield of BRRI dhan30. Bangladesh Res. Pub. J., 2: 397-405.

Jackson, ML, 1973. Soil Chemical Analysis. Prentice Hall of India Pvt. Ltd. New Delhi, India, pp. 69-182.

Kalala AM, NA Amuri and JMR Semoka, 2016. Sulphur and zinc fertilization effects on growth and yield response of rice. Int. J. Plant Soil Sci., 11: 1-12.

Khuang TQ, TT Huan and CV Hach, 2008. Study on fertilizer rates for getting maximum grain yield and profitability of rice production. Omonrice, 16: 93-99.

Knudsen D, GA Peterson and PF Pratt, 1982. Lithium, sodium and potassium. In: Page AL, RH Miller RH, DR Keeney (Eds.), Methods of Soil Analysis - Part 2. American Society of Agronomy, Inc. Publisher, Madison, pp. 225-245.

Li J, J Gao and Y Ma, 2010. Phosphorus accumation in soil in rice cropping systems with chemical fertilizer application: modeling and validation. World congress of soil science, soil solutions for a changing world, pp. 224- 227.

Massawe PI and J Mrema, 2017. Effects of different phosphorus fertilizers on rice (Oryza sativa L.) yield components and grain yields. Asian J Adv. Agric. Res., 3: 1-13.

Olsen SR, CU Cole, FS Watanabe and LA Dean, 1954. Estimation of available phosphorus in soil by extraction with sodium bicarbonate. Circular, U.S. Department of Agriculture, p 929.

Ram A, D Kumar, N Singh and A Anand, 2014. Effect of sulphur on growth, productivity and economics of aerobic rice (Oryza sativa). Indian J.Agron., 59: 404-409.

Russel DF, 1986. MSTAT-C package programme. Crop and Soil Science, Department, Michigan State University, USA.

Sanusan S, A Polthanee, S Seripong, A Audebert and JC Mouret, 2009. Rates and timing of phosphorus fertilizer on growth and yield of direct-seeded rice in rain-fed conditions. Acta Agric. Scand. Sec. B Soil Plant Sci., 59: 491-499.

Savci S, 2012. Investigation of effect of chemical fertilizers on environment. APCBEE Procedia, 1: 287-292.

Sharma SN, R Prasad, YS Shivay, MK Dwivedi, S Kumar S and D Kumar, 2009. Effect of rates and sources of phosphorus on productivity and economics of rice (Oryza sativa) as influenced by crop-residue incorporation. Indian J. Agron., 54: 42-46.

Singh AK, M Bushan, MK Meena and MA Upadhyaya, 2012. Effect of sulphur and zinc on rice performance and nutrient dynamics in plants and soil of Indo Gangetic Plains. J. Agr. Sci., 4: 162-170.

Uddin MH, KM Rahman, MZ Rahman, Z Alam and MA Salam, 2014. Effect of phosphorus and sulphur on yield of BRRI dhan57. J. Environ. Sci. Nat. Resour., 7: 7-11.

Vahed HS, P Shahinrokhsar and F Heydarnezhad, 2012. Performance of phoshate solubilizing bacteria for improving growth and yield of rice (Oryza sativa L.) in the presence of phosphorus fertilizer. Int. J. Agric. Crop Sci., 4: 1228-1232.

Walkey AJ and AI Black, 1934. Estimation of organic carbon by chromic acid titration method. J. Soil Sci., 25: 259-260.

White PJ and PH Brown, 2010. Plant nutrition for sustainable development and global health. Ann. Bot., 105: 1073-1080. 
Williams CH and A Steinbergs, 1959. Soil sulphur fractions as chemical indices of available sulphur in some Australian soils. Aust. J. Agric. Res., 10: 340-352.

Xi B, LM Zhai, J Liu, S Liu, HY Wang, CH Luo, TZ Ren and HB Liu, 2016. Long-term phosphorus accumulation and agronomic and environmental critical phosphorus levels in Haplic Luvisol soil, northern China. J. Integra. Agric., 15: 200-208.

Yosef TS, 2013. Effect of nitrogen and phosphorus fertilizer on spikelet structure and yield in rice (Oryza sativa L). Intl. J. Agril. Crop Sci., 5: 1204-1208. 